\title{
Multi drugs resistance to Diabetes Mellitus patients with tuberculosis in Manado City
}

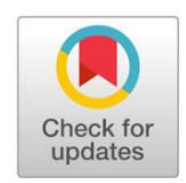

\author{
Elne Vieke Rambi $\square^{1 *}$, Dyan R. Sukandar ${ }^{1}$, Linda Augustien Makalew ${ }^{1}$, Yohanis \\ Tomastola $^{2}$, Ketrina Konoralma ${ }^{1}$ \\ 1 Department of Medical Laboratory Technology Politeknik Kesehatan Kementerian \\ Kesehatan Manado, Indonesia \\ 2 Department of Nutrition Politeknik Kesehatan Kementerian Kesehatan Manado, \\ Indonesia
}

\begin{abstract}
Diabetes mellitus (DM) with pulmonary tuberculosis (TB) is an infectious disease if not educated regularly, there will be a high risk of drug resistance and even some anti-tuberculosis drugs. This study aims to identify anti-tuberculosis drug resistance in DM patients with TB in Manado City. The population in the study types 2 DM patients as amount 80 patients. Based on TCM/GenExpert examination from 47 respondents, there were 17 respondents positive multi drugs resistance rifampicin (RR). Sampling taking based on inclusion criteria, i.e., have had type DM for five years, had suffered TB MDR RR based on GenXpert examination as much as 17 respondents followed in the resistance test with Sputum TB culture and MGIT method. The result of the study showed that MDR DM-TB with MGIT method as followed is obtained from 17 samples, six samples (35.30\%) resistance INH $0.4 \mathrm{mg}$ and 1 sample (5.88\%) MDR canamycin, and still sensitive INH $0.4 \mathrm{mg}$ and camaycin is ten samples (58.82\%). This study results could be used to program planning of prevention and controlling efforts TB-DM in this treatment obedience and regimen anti-tuberculosis medicine for MDR-TB patients.
\end{abstract}

Keywords: Diabetes Mellitus; Tuberculosis; Multi Drugs Resistant

\section{INTRODUCTION}

The risk factors that cause TB to become MDR TB are HIV coinfection, malnutrition, and smoking. Type 2 diabetes mellitus is a chronic metabolic disorder caused by impaired function of pancreatic beta cells which causes progressive insulin resistance and chronic inflammation. ${ }^{-}$Wan-Mei conducted the research in China on 2004-2007 got founding that MDR-TB is more highest on DM patients than non DM. $\stackrel{2}{ }$

Other studies have reported the association between diabetes and MDR TB, but the results were controversial, and their samples were not enough. In addition, there remains a paucity of information about the relationship between diabetes and various subgroups of primary DR-TB and clinical characteristics of TB-DM cases, especially in China, which had the second-highest burden of TB in 2017. ?

Compounding the problem, increasing drug resistance also poses a grave threat to TB control it requires more sophisticated laboratory infrastructure. However, the development of Xpert/MTB/RIF, a real-time PCR (rt-PCR) assay that can diagnose TB and detect rifampicin resistance concurrently has revolutionized the diagnosis of drug-resistant tuberculosis (DR TB). Very 
importantly, in the same policy statement which emphasizes that DST for anti-TB medicines other than rifampicin should also be offered..$^{3}$ Thus, along with TB diagnosis, drug susceptibility testing (DST) has become an urgent clinical requirement for a timely constitution of proper and effective TB treatment. However, TB diagnostic and laboratory capacity are still deficient in many areas of highly TB-burdened countries. It causes a crucial barrier to detecting human immunodeficiency virus (HIV)-associated and drug-resistant tuberculosis. ${ }^{4}$

\section{MATERIAL AND METHOD}

The population in the study are types 2 DM patients as much 80 patients with 46 respondents had comorbidities. Based on TCM/GenExpert examination from 47 respondents, there were 17 respondents positive multi drugs resistance rifampicin (RR). Sampling taking based on inclusion criteria, i.e., have had type DM for five years, had suffered TB MDR RR based on GenXpert examination as much as 17 respondents followed. The resistance test with Sputum TB Culture and MGIT Method. The tools used in this research include TCM cartridges, GeneXpert, and Bactec MGIT 960.

\section{RESULTS AND DISCUSSION}

The results of the research carried out can be seen in the following picture

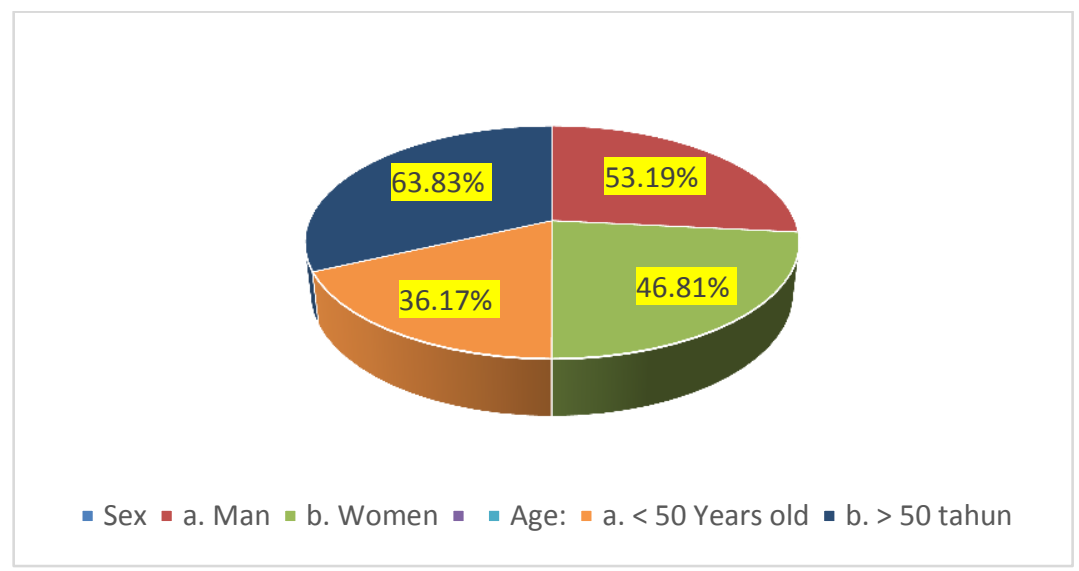

Figure 1. Distribution Sex and Age MDR-TB Patients

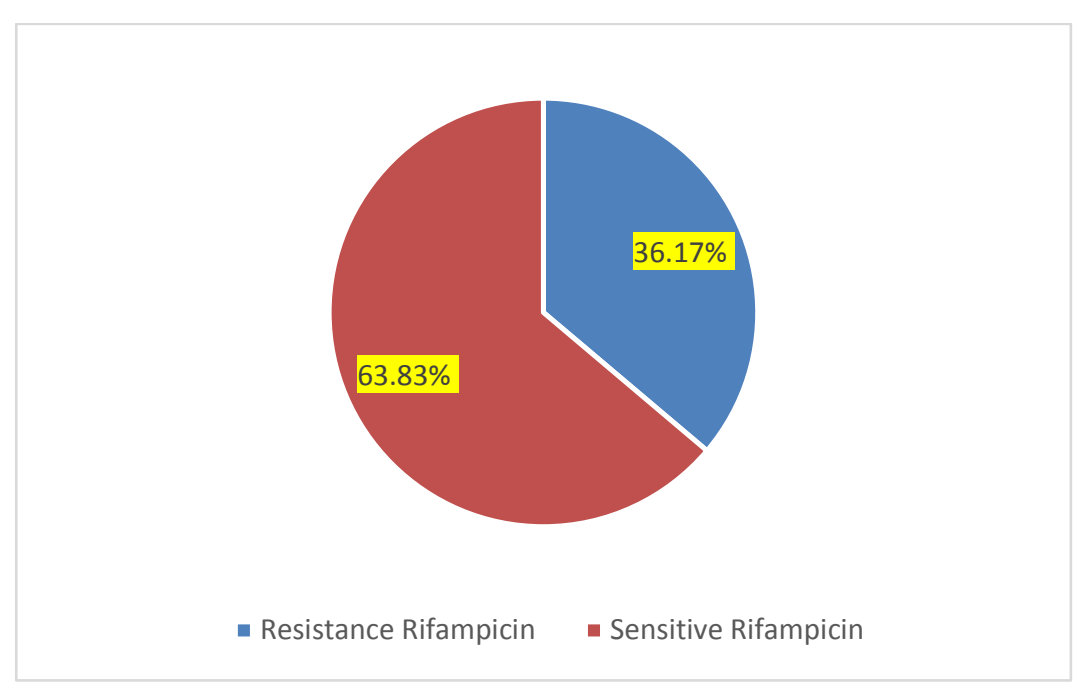

Figure 2. Results of TCM/GenXpert MDR DM-TB Patients 


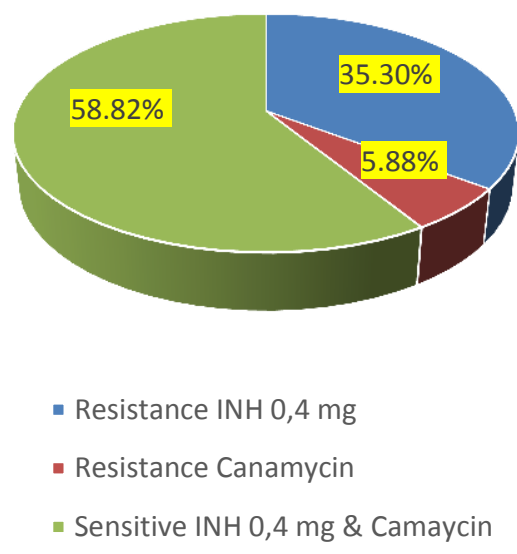

Figure 3. Result of MDR DM-TB with MGIT Method

While data in figure 3 showed that examination results about MDR DM-TB with MGIT method as followed is obtained from 17 samples, six samples $(35.30 \%)$ resistance INH $0.4 \mathrm{mg}$ and 1 sample (5.88\%) MDR canamycin, and still sensitive INH $0.4 \mathrm{mg}$ and camaycin is ten samples (58.82\%). TCM as tools which could existence Mycobacterium tuberculosis detection as soon. The sensitivity level of tools reaches $98.3 \%$, and sensitivity is $99 \%$.,

The growing prevalence of TB-DM comorbidity worldwide has provided a new challenge to clinical management and health systems control strategy. It was observed that patients who have DM complicated with TB often experience delayed sputum culture conversion, increased risk of death and recurrence. What is more, the emergence of MDR-TB makes the adverse anti-TB treatment outcomes in TB-DM comorbidity even worse, which may increase the treatmentrelated economic burden, promote the transmission of MDR-TB, and even accelerate the generation of extensively drug-resistant-TB (XDR-TB).,,$\underline{7}$

The reasons for a higher MDR rate in patients with TB-DM comorbidity are not thoroughly understood, however, they may differ by different MDR type (primary or secondary). ${ }^{7}$ The combination of the impaired immune system in DM and bacterial genetics might be a reasonable explanation for primary MDR. It has been reported that poor glucose control is often associated with dysfunction of phagocytosis, reactive oxygen species (ROS) production, chemotaxis, and T-cell reaction in DM patients. On the other hand, MDR strains are shown to be less virulent due to heterogeneous mutations, and they are less likely to lead to secondary TB cases compared with drug-sensitive strains 41-43. Then the less fit MDR strains are more likely to flourish in immunocompromised DM patients, which leads to the higher primary MDR-TB in those patients. The situation seems to be more complex concerning the mechanisms of secondary MDR-TB in DM. Possible explanations include higher mycobacterial burden, altered pharmacokinetics of anti-TB drugs, and lower treatment adherence, which promote the selection of MDR strains by anti-TB drugs., $, 9,10$ The drug-susceptible M. tuberculosis isolates were susceptible to all four (rifampicin, isoniazid, ethambutol, and streptomycin) drugs tested (pansusceptible strains).., 10

Drug susceptibility testing results were retrieved for 502 isolates from 490 patients. Ten patients had results for two isolates at different time points, and one patient had results for three isolates. Among the 490 patients with a DST result, 55.0 and $63.1 \%$ had resistance to pyrazinamide and ethambutol, respectively. $\frac{10}{}$ Although these drugs are not used in regimen 1 or 2 , the high resistance rates might be explained by easy access to antibiotics without prescription in Vietnam. HIV co-infection, positive baseline AFB smear, older age, and previous treatment with second-line drugs are the main risk factors for poor treatment outcomes in 
our cohort, which were also observed in Estonia, Latvia, Philippines, Russia, Peru, and Ukraine. Malnutrition was common (57.8\%) and a risk factor for poor outcome (OR: 0.81 for every $1 \mathrm{~kg} / \mathrm{m} 2$ increase of BMl). Low BMl might be a consequence of severe disease and low socioeconomic status, which are wellknown risk factors for poor outcomes in TB. ${ }^{10}$ On the other hand, studies conducted in Thailand and Fiji indicated that the death rate was similar in both TBDM and TBNDM patient groups. 11 DM prevalence increased, and TB disease incidence declined, DM was predicted to play a significant and growing role in TB epidemiology..$\underline{.}$

More extended sputum conversion describes more drugs to which $M$. tuberculosis is resistant. The effectiveness of second-line anti TB drugs in MDRTB patients is best evaluated in the first eight weeks of administration. ${ }^{13}$ The TB and DM interactions potentially cause adverse impact by increasing each other's complications, making diagnosis and treatment more difficult, worsening disease course and outcome. $\frac{14}{}$ Current TB treatment and control levels in the public sector have led to lower levels of MDR TB prevalence than if TB treatment had been provided exclusively by private-sector clinics that do not follow effective TB treatment protocols. If DOTS had never been implemented and instead the private sector had expanded to cover half of the population, MDR TB prevalence would be approximately 33\% larger in 2038 - rising from 32 per 100,000 in 2013 to 56 per 100,000 in 2038. $15, \underline{16}, 17$ MDR-TB, especially untreated MDR-TB, would rise rapidly under China's current MDR-TB control strategies. Interventions designed to promote effective detection and treatment of MDR-TB are imperative in the fights against MDR-TB epidemics. $\frac{18}{}$ Expansion of diagnosis and treatment of MDR-TB, even using current sub-optimal second-line regimens, is expected to decrease MDR-TB incidence at the population level significantly. Focusing MDR diagnostic efforts on previously-treated cases is an efficient first-step approach. ${ }^{19}$

\section{CONCLUSION}

Only $0.4 \mathrm{mg}$ IN and clindamycin can be used to treat TB in Manado City. This study results could be used to program planning of prevention and controlling efforts TB-DM in this treatment obedience and regimen anti-tuberculosis medicine for MDR-TB patients.

\section{AUTHORS' CONTRIBUTIONS}

All authors contributed equally to this work.

\section{FOUNDING INFORMATION}

The funding for this research was sourced from the Health Polytechnic of the Manado Health Ministry.

\section{DATA AVAILABILITY STATEMENT}

The utilized data to contribute to this investigation are available from the corresponding author on reasonable request.

\section{DISCLOSURE STATEMENT}

The views and opinions expressed in this article are those of the authors and do not necessarily reflect the official policy or position of any affiliated agency of the authors. The data is the result of the author's research and has never been published in other journals.

\section{REFERENCE}

1. Ulfahimayati U, Medison I, Mizarti D. Diabetes Mellitus Tipe 2 sebagai Faktor Predisposisi dan Komorbid Tuberkulosis Multi Drug Resisten Primer. J Kedokt Yars. 2020;28(2):041-050. doi:10.33476/jky.v28i2.1422.

2. Song $\mathrm{W}$, Shao $\mathrm{Y}$, Liu J, et al. Primary drug resistance among tuberculosis 
patients with diabetes mellitus: a retrospective study among 7223 cases in China. Infect Drug Resist. 2019;Volume 12:2397-2407. doi:10.2147/IDR.S217044.

3. Zaragoza B, Laniado-Laborín R. Diagnosing Drug-Resistant Tuberculosis with the Xpert®MTB/RIF. The Risk for Rifampin Susceptible Cases. J Tuberc Res. 2017;05(03):155-160. doi:10.4236/jtr.2017.53017.

4. Aung MN, Moolphate, Aung M, et al. Prospective evaluation of simply modified MODS assay: an effective tool for TB diagnosis and detection of MDR-TB. Infect Drug Resist. 2012;5(1):79. doi:10.2147/IDR.S24295

5. Siahaan AGH, Polii EBI, Ongkowijaya J. Profil pasien tuberkulosis dengan multi drug resistance (MDR). J e-Clinic. 2016;4. https://ejournal.unsrat.ac.id/index.php/eclinic/article/view/14498/14071.

6. Novianti N, Simarmata OS, Lolong DB. Pemanfaatan Tes Cepat Molekuler (TCM) Genexpert Sebagai Alat Diagnostik TB Paru di RSUD Wangaya Kota Denpasar. J Ekol Kesehat. 2020;18(3):135-148. doi:10.22435/jek.v3i18.2399.

7. $\quad$ Aderita NI, Murti B, Suryani N. Risk Factors Affecting Multi-Drug Resistant Tuberculosis in Surakarta and Wonogiri, Central Java, Indonesia. J Epidemiol PublicHealth. 2016;01(02):86-99. doi:10.26911/jepublichealth.2016.01.02.02.

8. Rumende CM. Risk Factors for Multidrug-resistant Tuberculosis. Acta Med Indones. 2018;50(1):1-2. http://www.ncbi.nlm.nih.gov/pubmed/29686169.

9. Mulu W, Mekkonnen D, Yimer M, Admassu A, Abera B. Risk factors for multidrug resistant tuberculosis patients in Amhara National Regional State. Afr Health Sci. 2015;15(2):368. doi:10.4314/ahs.v15i2.9.

10. Gomes M, Correia A, Mendonça D, Duarte R. Risk Factors for DrugResistant Tuberculosis. J Tuberc Res. 2014;02(03):111-118. doi:10.4236/itr.2014.23014.

11. Rodal C. Tuberculosis, Enfermedad Infecciosa Más Letal En El Mundo. Boletín UNAM-DGCS-187bis Ciudad Univ. 2018;44(2):145-152. https://www.dgcs.unam.mx/boletin/bdboletin/2018 187bis.html.

12. Wijaya I. Tuberkulosis Paru pada Penderita Diabetes Melitus. Cermin Dunia Kedokt. 2015;42(6):412-417. http://www.cdkjournal.com/index.php/CDK/article/view/996.

13. Soeroto AY, Pratiwi C, Santoso P, Lestari BW. Factors affecting outcome of longer regimen multidrug-resistant tuberculosis treatment in West Java Indonesia: A retrospective cohort study. Marotta C, ed. PLoS One. 2021;16(2):e0246284. doi:10.1371/journal.pone.0246284.

14. Widyaningsih $P$, Nugroho AA, Saputro DRS, Sutanto. Tuberculosis transmission with relapse in Indonesia: susceptible vaccinated infected recovered model. J Phys Conf Ser. 2019;1217(1):012071. doi:10.1088/1742-6596/1217/1/012071.

15. Suen S, Bendavid E, Goldhaber-Fiebert JD. Disease Control Implications of India's Changing Multi-Drug Resistant Tuberculosis Epidemic. Dowdy DW, ed. PLoS One. 2014;9(3):e89822. doi:10.1371/journal.pone.0089822.

16. Wai PP, Shewade HD, Kyaw NTT, et al. Community-based MDR-TB care project improves treatment initiation in patients diagnosed with MDR-TB in Myanmar. Shankar EM, ed. PLoS One. 2018;13(3):e0194087. doi:10.1371/journal.pone.0194087.

17. Hossain ST, Isaakidis P, Sagili KD, et al. The Multi-Drug Resistant Tuberculosis Diagnosis and Treatment Cascade in Bangladesh. Subbian S, ed. PLoS One. 2015;10(6):e0129155. doi:10.1371/journal.pone.0129155.

18. Li B-Y, Shi W-P, Zhou C-M, et al. Rising challenge of multidrug-resistant tuberculosis in China: a predictive study using Markov modeling. Infect Dis Poverty. 2020;9(1):65. doi:10.1186/s40249-020-00682-7. 
19. Kendall EA, Azman AS, Cobelens FG, Dowdy DW. MDR-TB treatment as prevention: The projected population-level impact of expanded treatment for multidrug-resistant tuberculosis. Chatterji D, ed. PLoS One. 2017;12(3):e0172748. doi:10.1371/journal.pone.0172748. 